Article

\title{
Toward Regeneration of Public Open Spaces within Large Housing Estates-A Case Study of Niš, Serbia
}

\author{
Ivana Bogdanović Protić * , Petar Mitković and Ljiljana Vasilevska \\ Faculty of Civil Engineering and Architecture, University of Niš, Aleksandra Medvedeva 14, 18106 Niš, Serbia; \\ petar.mitkovic@gaf.ni.ac.rs (P.M.); ljiljana.vasilevska@gaf.ni.ac.rs (L.V.) \\ * Correspondence: ivana.bogdanovic@gaf.ni.ac.rs; Tel.: +381-63-465-228
}

Received: 7 October 2020; Accepted: 2 December 2020; Published: 8 December 2020

check for

updates

\begin{abstract}
Despite the multiple contributions of public open spaces (POSs) to the quality of life in large housing estates (LHEs), the comprehensive treatment of their improvement has so far been a rare occasion in post-socialist countries. This paper aimed to explore the transformations of POSs in inherited LHEs in the socialist and post-socialist period and the potential for their regeneration. The investigation was based on a comparative analysis of two case studies in Niš, Serbia, which represent typical modes of POS devastation. The performed research study has shown that POSs have succumbed to dilapidation, displaying a wide array of problems and that their regeneration is neglected. The paper proposes a comprehensive set of measures to regenerate POSs based on contemporary concepts of urban planning and design with a special focus on long-term actions and residents' needs. Particular importance is given to establishing the development guidelines as future prerequisites for overcoming current institutional, economic, legislative, and social obstacles for sustainable implementation of regeneration measures. These findings might encourage future studies of creating a model option for improving POSs at the city of Nis scale, as well in other Serbian cities towards sustainable urban development.
\end{abstract}

Keywords: large housing estates; public open spaces; urban regeneration; quality of life; Niš

\section{Introduction}

Public open spaces (POSs) in inherited large housing estates (LHEs), which are present throughout Europe in all their variations regardless of the sociopolitical order and the level of economic development, are an integral component of the spatial functional structure and the living environment. Despite the conceptually fascinating ideas, over the last few decades, many of these areas have been facing serious physical, social, environmental, and economic deterioration. They often include degraded urban areas, with dilapidated and neglected POSs, which are unattractive for human living [1-4]. Although the problem of POS devastation is present in many European countries, the focus of this paper is on POS in inherited LHEs in post-socialist countries, where this problem is incomparably more prevalent. As opposed to western European countries, where LHEs are prevalently occupied by lower-income residents, in the LHEs of post-socialist countries, the apartments are usually reserved for the middle class and young families with children [5-7], who are also the most frequent users of POS.

After the 1990s, socioeconomic changes, transition, recession, changes in urban policies, and other factors created a new urban reality in post-socialist cities. One of the outcomes in which these changes are particularly prominent involves inherited LHEs, so the issue of their urban regeneration has become a priority. Most LHEs built after WW2 were built according to the CIAM urban design principles. This resulted in spacious blocks and generous POSs between the residential blocks and buildings [8]. Similar to the LHEs within which they were developed, the large planned POSs, incompatible with the measure of man and inadequately equipped due to inconsistent implementation 
of the plans, were exposed to long-lasting deterioration and gradual loss of their basic functionality. The POSs underwent the same spatial and functional changes as the areas containing the LHEs. The types of transformation in inherited post-socialist LHEs depended on the way national and local authorities responded to their development. In that context, three modes of transformation were identified [7,9-11]: (1) complete demolition of existing dilapidated LHEs and construction of new residential buildings [9,12]; (2) uncontrolled and partial interventions resulting from inadequate policies and insufficient financial interventions with minimum national and local government participation, whereby the focus was most often on the improvement of residential buildings' energy efficiency and POS regeneration; and (3) fully renovated urban regeneration projects, based on an overall spatial, functional, environmental, and social development [13].

The political and economic changes that influenced the changes in LHEs in former socialist countries and that are known for their various issues-deterioration of physical structures, social problems, insecurity, poor image, and neglect of POSs-were considered in several previous studies $[7,14]$. These studies suggest that the said changes have been characterized by an array of negative impacts on the social values system and the quality of life in LHEs, with special emphasis on the poor state and neglect of POSs. However, the problem of POS regeneration in inherited LHEs has not been properly handled in former socialist countries, even though urban renewal projects for LHEs have been initiated and implemented since the 1990s (in some countries). Few previous studies have dealt with the state of POSs in LHEs in post-socialist cities $[7,15-18]$ and they propose several measures that offer just short-term improvements. In Serbia, the academic research dealing with the current problems and prospects for the regeneration of POSs in LHEs is modest $[19,20]$. This issue has been most investigated so far by Bogdanovic [13], on which this research relies. However, in this paper, the comprehensive improvement of POSs is further elaborated and significantly improved towards sustainability. Therefore, the present study will be significant to the academic community and for the improvement of POSs in inherited LHEs. This paper focuses on the aforementioned type 2 of POS transformation, considering that this mode of inherited LHEs is characteristic of Serbia.

The general objective of this paper was to determine and define a comprehensive set of measures and activities for the long-term improvement of POSs in inherited LHEs in post-socialist countries in keeping with the current tendencies of urban design and the needs of residents. The research was conducted on two representative LHEs in Niš, a second-tier city in Serbia. Considering that POSs in LHEs are marginalized and neglected spaces, incompatible with the residents' actual needs, and lacking local-level initiatives [13], it can be claimed that Niš is a representative example for a current state analysis of POSs within LHEs, their transformation during the period of transition, and the potentials for their improvement. Conducting such a study should be important for defining the character and an overall level of dilapidation of POSs in inherited LHEs and determining types of possible measures for improvement at the local level, but also for understanding the broader spatial, economic, and social reality in today's Serbia to develop effective LHEs regeneration strategies.

In addition to exploring the potential for long-term improvement of POSs in inherited LHEs, the paper is organized around three key research aims:

- Firstly, we investigated whether the changes and development trends of LHEs in the post-socialist period are reflected in the transformation flows of POSs in inherited LHEs and degradation and what are the types of that changes of POSs;

- Secondly, we investigated whether it is possible to define long-term development measures for the regeneration of POSs and what are the types of those measures;

- Thirdly, we investigated whether in the current local planning regulations and with the local organizational and economic circumstances in Nis it is possible to apply defined regeneration measures, what are the restrictions for their implementation, and what are the development requirements and guidelines for their efficient application. 
Due to the fact that the issues explored in this study are very complex and can be viewed through several aspects relevant for residents satisfaction with POSs, the focus of this paper was on certain spatial and functional, psychosocial, environmental, and visual and aesthetic aspects that were adopted as most important for residents' satisfaction with POS quality in the immediate residential environment. Given that Serbia does not have an adequate planning framework relevant to this issue, nor strategic initiatives for comprehensive improvement of POSs in inherited LHEs, detailed public policy field research is beyond this study, and can be the subject of some further research.

The first part of the paper provides a theoretical and contextual framework for the understanding of POS within inherited post-socialist LHEs in Serbia. Following the applied methodology, the paper investigates the potential for improving POSs in inherited LHEs through a case study of two representative areas in Niš and considers the POS transformation during the post-socialist period, the current issues, and possible regeneration measures, while focusing on the limitations and requirements for their implementation. The final part formulates the conclusions and recommendations for the application of identified measures for POS improvement and highlights the need to establish an integrated approach to POS regeneration, both legally and strategically.

\section{Characteristics of Public Open Spaces within Inherited Large Housing Estates in Post-socialist Serbia: Setting and Framing the Context}

Examination of the characteristics of POSs within inherited LHEs in Serbia requires a more detailed analysis of the transformations that the LHEs underwent where they had been developed. Namely, the modes of transformations of LHEs influenced the types of changes of the POSs contained within them. The sections below describe the chief characteristics of LHEs in the socialist and post-socialist period and the current spatial and organizational characteristics of POSs within LHEs.

\subsection{Large Housing Estates in the Socialist Period}

LHEs developed after WW2 in Serbia, as well as throughout the other former socialist countries, constitute a substantial portion of the housing stock, as they house a large number of residents. They represent the most significant achievements of the socialist society, characterized by giving political priority to the public interest. The period in which most of the estates were built was also characterized by a population explosion due to the post-WW2 baby boom [21] and their development became the instrument for meeting the enormous housing demands. From the 1960s to the mid-1980s, more than 34 million buildings were erected [22] and as much as $20-40 \%$ of the total population live in them (up to $72 \%$ in some countries). LHEs were often developed outside the traditional inner cities and according to the principles of CIAM [23], whereby their main features included repetition of monotonous urban ensembles, low construction standards for apartment buildings to cut costs [24], and the construction of lavishly large POSs. All of the above was intended to create social equality, as egalitarianism and uniformity prevailed over individualism and diversity [25], but consequently, it led to the creation of impersonal residential blocks, without the basic visual values, uncoordinated with a human perspective [26]. Despite the issues that emerged as early as the 1980s, construction of LHEs continued until the 1990s [27]. Construction of LHEs was accompanied by the formal revocation of ground rent, i.e., by the devaluation of development land and the dissolution of the market, which also affected the POSs.

The approach to the spatial organization of POSs in Serbia often involved large vacant spaces between buildings, which had a completely anonymous character, since they were often treated as intact landscapes, that is, they were not formalized through any planning documentation and were not equipped properly [25]. Any of the more ambitious solutions for POS planning did not usually go far beyond the planning stage, being either partially completed or not completed at all, primarily due to the lack of financing. The POSs were characterized by an impersonal urban design, which often caused problems such as reduced security and lack of social control [28]. One of the key issues that caused degradation of POSs during the socialist period was the absence of a regular maintenance strategy and 
inadequate management, which were under the jurisdiction of municipal public utility companies, which ran on a tight budget.

\subsection{Large Housing Estates in the Post-socialist Period}

In the late 1980s and early 1990s, especially after the dissolution of former Yugoslavia, Serbia underwent substantial social, political, economic, and spatial changes, transitioning, and economic crisis. In the context of spatial planning, serious consequences of the long-lasting transition are reflected in disharmonious development policies and radical changes in the housing policy, all of which affected the state of LHEs inherited from the socialist period. In addition to these changes, the inherited LHEs were also privatized, numerous new housing units were built as rooftop extensions of the existing residential buildings, some buildings were overhauled, and new buildings were erected on former green spaces. The mentioned changes are characteristic of the second mode of LHE transformations, which influenced the transformation type of the associated POSs in Serbia. These main key changes that can be recognized in POSs in inherited LHEs are obsolescence and destruction of existing urban equipment, reduction of the usability of POSs, neglect, and modest interventions by minimal residents' inadequate maintenance and management and increased anti-social behavior at POSs.

As it is indicated in Country Profiles on the Housing Sector Serbia and Montenegro [29] the mass privatization policy in Serbia occurred over a relatively short period and it constituted a radical transformation of ownership, whereby state-owned apartments were sold to the residents below market value, followed by cuts in state funding [30]. By 1995, almost $98 \%$ of the apartments in Serbia were privately owned, resulting in the formation of super-homeownership societies [7,31]. Due to the country's economic collapse and mass privatization, the idea of establishing building and POS maintenance funds quickly ended the privatization without the expected financial effect [32]. In parallel with the privatization, there were also changes in terms of maintenance jurisdiction, accompanied by the collapse of state-owned companies and housing authorities, which led to a series of issues and continued the degradation of LHEs and POSs, initiated in the socialist period [33].

In addition to the state bodies and local self-government units, private investors also became involved in urban regeneration, while the institutional context was dictated by the political and economic recession, which has lasted from the 1990s to date. After the Law on the Construction of Rooftop Extensions and the Conversion of Common Areas into Apartments [34] was passed, mass construction of rooftop extensions ensued in the inherited residential buildings. Although the law stipulated only small-scale construction of rooftop extensions, there were frequent deviations from the terms stated in the temporary construction licenses, including the permitted building coverage ratio, the required number of parking spaces, and the allowed area of green space per resident. In addition to rooftop extensions, new building construction also took place over other public and green spaces. Due to an increase in the number of residents oriented towards the existing POSs, as well as due to the construction of new buildings on some of the POSs, there has been a reduction in the area of POSs and greenery per resident. Such urban transformations have been caused by the changed legislative framework and institutional circumstances, manifesting in the changing roles of subjects in the field of urban planning, landscaping, and POS regeneration on the national and local self-government levels.

One of the key issue for the dilapidation of POSs also lie in unresolved ownership status of the development land, unclear legislative treatment, and the absence of standards and norms. The enacted regulations only partially regulate the effects of mass privatization and the maintenance aspect, which are caused by (1) deficient laws and (2) deficient by-laws and institutional support, rendering the enforcement of the laws inefficient [35]. Although POSs in LHEs are the key determinants for the quality of life, these spaces in Serbia are referred to as spaces between buildings or as interblock green space [36]. Due to the lack of laws that would deal with the spatial functional organization of POSs, there are no clearly defined regulations, except for municipal decisions, that define what green and public areas are. Devaluation of their importance by the legislation, aided by inadequate management and maintenance under current conditions negatively impacts the current state of POSs $[13,37]$ in 
inherited LHEs. Similar to other former socialist countries [38], POSs have been marginalized and have become places of neglect and decline. Several studies suggested that the neglect of POSs contributes to the deterioration of the residents' fundamental living values and their quality of life [37,39-42] and that their regeneration should be a priority for the sustainability of the LHEs in which they were built. The undefined national housing policy in the domain of improving POS in inherited LHEs should be especially emphasized, as well as the fact that present problems of POS are not adequately considered in the planning practice in Serbia. Strategic initiatives for the development of POSs in inherited LHEs do not exist, and the current planning framework is not overshadowed by participatory planning, which is essential for the improvement of POS.

\subsection{Public Open Spaces within Inherited Large Housing Estates—Setting the Context}

As has been proposed elsewhere in the literature, the quality of POSs is an important factor influencing the quality of life in LHEs. In the present study, POSs refers to organized and equipped open unbuilt spaces around and between buildings, containing only pedestrian traffic, having a variety of purposes, contributing to the fulfillment of various human needs, and playing a crucial role in the shaping of the residential area. They are important for the physical and psychological wellbeing of residents and they are used for various functional and symbolic purposes [43], while their layout provides an appropriate surrounding for the nurturing of a sense of community. This paper is based on the argument that the quality of POSs is the key factor for making LHEs vital and sustainable living spaces. Given the numerous needs and requirements for POSs within inherited LHEs, the quality of their spatial and organizational characteristics should be determined according to several different aspects. A review of numerous studies on the current trends of equipment, organization, and shaping of POSs indicates that there are no clear quality criteria for POSs in inherited LHEs [44,45]. Accordingly, this study relies on the idea that the good quality of POSs is achieved if the residents of LHEs are satisfied, which is attainable through the integrated application of the following groups of criteria: spatial and functional, psychosocial, environmental, visual and aesthetic, and technological and organizational [13,46-49].

The quality of POSs can primarily be observed from the functional and the social perspective, whereby the two perspectives often overlap. Thus, the primary function of POSs involves providing space for every day or temporary use and the performance of necessary or optional leisure activities [46,50]. When residents spend their leisure time in the immediate surroundings of their home, it can help them identify with their residential surroundings and build stronger social relations [51,52]. Green areas inside of POSs are key issues for LHE microclimate improvement [53]. Previous studies [50,54-57] concluded that POSs should have a hierarchic order, while the spatial organization and urban equipment need to be properly implemented, in keeping with the POS function. The variety of content offered by the aforementioned activities can motivate the residents to use POSs for social interactions. As suggested by Alexander [58]: "POSs allow the residents to feel comfortable outside their apartment buildings, to strengthen their sense of territoriality and privacy, and to feel connected to the community of other residents". The motivation of residents involves the need to participate in various activities and it is reflected in how much they enjoy staying in them. What is particularly important is the residents' need to identify with them and develop a sense of belonging [59]. The quality of urban design is one of the key determinants of the visual and aesthetic components of POS quality. The key elements of good urban design of POSs include the following: quality of urban equipment; vegetation, landscape elements, and walking paths; appropriate size and number of shaded sitting spaces; sculptures; bodies of water; and various types of pavements [60]. The colors, styles, and shapes used in POSs can positively or negatively influence the residents' emotions and behavior by stimulating them motivationally, generating a sense of comfort, or by inducing boredom and aversion [57], which is why these elements should be emphasized during the design of POSs.

In recent years, city planners have expended much effort to create a pleasant residential environment, to regenerate POSs, and to improve the living conditions in the LHEs throughout 
post-socialist countries [7,61-63]. Yet, even though most POSs within inherited LHEs in Serbia are dilapidated, except for partial interventions, the urban regeneration practice in Serbia concerning POSs is completely neglected. This indicates that regeneration of POSs in inherited LHEs in Serbia while covering the aforementioned various aspects of quality that can meet the fluctuating long-term demands of the residents is one of the biggest challenges of urban planning. Improving POSs can improve the actual living conditions in LHEs while infusing a sense of hope and a better image in the eyes of the residents and the outside world [38]. Therefore, it is particularly important to prevent further negative tendencies of the development of POSs within LHEs and to devise development guidelines for their urban regeneration towards sustainability.

\section{Methodology}

\subsection{Methods}

The methodology used in this study was based on the use of the empirical method, analysis, synthesis, and case study, since the main goal of this exploratory study was to determine and define a comprehensive set of measures and activities for long-term improvement of POSs in inherited LHEs in post-socialist countries in keeping with the current tendencies of urban and design and the needs of residents. Both qualitative and quantitative methods were used in this study. Data collection included national and local statistics, official planning, and legislative documents. Quantitative methods were used for the analysis of individual cases.

The literature review is used to provide the post-socialist context of the urban development of LHEs, to provide insight into the transformation of POSs within inherited LHEs in former socialist countries and Serbia, and to identify the criteria of POS quality in modern urban design approaches. In order to perform a detailed study of characteristics, problems, and intensity of deprivation, the typical socialist POSs in LHEs in the wide central and outskirt location of the city of Nis were chosen. For that purpose, the paper analyzed the current state of POSs in two representative areas within LHEs using an empirical study based on (1) literature review, (2) practical experience with the areas under observation and collected empirical data on the POSs, and (3) a survey of the residents of LHEs, whose opinions and needs are crucial for POS regeneration. Data collection for the investigation of selected POSs relied also on local statistical data, official planning documents, and the current laws.

For identification and evaluation of characteristics and types of represented problems and level of deprivation of POSs within LHEs in Nis, spatial and functional, psychosocial, environmental, and visual and aesthetic criteria were established, forming an all-encompassing values system for the human values of POSs, which is presented in Table 1 . The selection of the criteria was based on several previous studies [45-49], which are incorporated in the methodology for the identification and evaluation of characteristics and problems of POSs. This methodology was first developed by Bogdanović [13] to evaluate the POSs in inherited LHEs and was further applied in this paper to best suit the purpose of this research. This paper relies on the idea that the good quality of POSs can be achieved if the residents of LHEs are satisfied, which is attainable through an integrated application of the criteria stated above. Each of these quality criteria was first analyzed according to the researcher's observations and the survey conducted on LHE residents and then used to evaluate the current state of POSs and proposed development guidelines. Since the issue of perceiving the satisfaction of POS residents is very complex, this research did not cover all issues that can be considered relevant for residents' satisfaction with POS, but those that are of the greatest importance for most residents' perception of the quality of POS in the immediate of their living environment. Table 1 provides a wide multidimensional foundation of POS quality aspects, which are evaluated through specific indicators developed based on comprehensive theoretical research. The evaluation relies on the proposed three-point scale with the following symbols: ${ }^{* * *}$, and ${ }^{* * *}$. The symbol ${ }^{*}$ denotes insufficient or the absence of the given POS quality aspect, symbol ** indicates that the analyzed POS quality aspects are present but insufficiently prominent, symbol ${ }^{* * *}$ indicates a considerable presence of the 
analyzed POS quality aspect. These key quality aspects of POSs in Table 1 were also used to define a comprehensive set of improvement measures of POSs towards sustainability.

The main determinants of the psychosocial criterion of quality comprise safety, privacy and territoriality, social interaction, and good neighborly relations. Safety contains the following indicators: lighting; visibility and possibility of POS control from apartments, with clear space boundaries; separation of pedestrian and motor vehicle traffic; the presence of antisocial behavior; parking in POSs; urban design quality; and maintenance of POSs. The following indicators monitor privacy and territoriality: public/private delineation; personalization of space through the creativity of the residents; sufficient space for peace, harmony, and noise protection; protection from unwanted looks; a sense of security; adequate space size. Social interaction and good neighborly relations are deemed favorable depending on the following indicators: good communication among neighbors; gathering of neighbors; equipment of spaces for meetings, joint activities, and games [59,64]. Evaluation is especially positive when the following indicators are present: residents desire to spend time in POSs and frequency of use; residents' participation in POS spatial organization and maintenance $[65,66]$, whereby the development of collective urban gardens is particularly prominent, through which they revitalize social ties and a sense of community on a local level [67].

Table 1. A methodology for the identification and evaluation of characteristics and problems of public open spaces (POSs) in chosen areas. Source: Bogdanovic [13].

\begin{tabular}{|c|c|}
\hline KEY ASPECTS & SPECIFIC INDICATORS \\
\hline \multirow{10}{*}{$\begin{array}{l}\text { USABILITY, DIVERSITY, AND } \\
\text { ACCESSIBILITY } \\
\text { KA1 }\end{array}$} & KA1.1-Accessibility \\
\hline & KA1.2-Multifunctionality and options for various types of activities \\
\hline & KA1.3-Urban design \\
\hline & KA1.4-Compatibility with the needs of the residents \\
\hline & KA1.5-Ease of access from the apartment buildings \\
\hline & KA1.6-Visibility \\
\hline & KA1.7-Public/private delineation \\
\hline & KA1.8-Availability of content for different age groups of the residents \\
\hline & KA1.9-Size of POSs \\
\hline & KA1.10-Maintenance of POSs \\
\hline \multirow{4}{*}{$\begin{array}{l}\text { URBAN DESIGN } \\
\text { KA2 }\end{array}$} & KA2.1-Urban equipment \\
\hline & KA2.2-Landscaping \\
\hline & KA2.3-Materialization \\
\hline & KA2.4-Variability and flexibility \\
\hline \multirow{2}{*}{$\begin{array}{l}\text { HEALTH AND COMFORT } \\
\text { KA3 }\end{array}$} & KA3.1-Favorable microclimate \\
\hline & KA3.2-Minimization of motor vehicle traffic \\
\hline \multirow{7}{*}{$\begin{array}{l}\text { SAFETY } \\
\text { KA4 }\end{array}$} & KA4.1-Lighting \\
\hline & KA4.2-Visibility, the possibility of control, and clear boundaries of the space \\
\hline & KA4.3-Separation of pedestrian and motor vehicle traffic \\
\hline & KA4.4-Antisocial behavior \\
\hline & KA4.5-Urban design \\
\hline & KA4.6-Maintenance of POSs \\
\hline & KA4.7-Parking in POSs \\
\hline \multirow{7}{*}{$\begin{array}{l}\text { PRIVACY AND TERRITORIALITY } \\
\text { KA5 }\end{array}$} & KA5.1-Public/private delineation \\
\hline & KA5.2-Personalization of space through the creativity of the residents \\
\hline & KA5.3-Sufficient space for peace, harmony, and noise protection \\
\hline & KA5.4-Adequate space size \\
\hline & KA5.5-Protection from unwanted looks \\
\hline & KA5.6-Sense of security and safety \\
\hline & KA5.7-Activity schedule, conflicts \\
\hline \multirow{5}{*}{$\begin{array}{c}\text { SOCIAL INTERACTION AND } \\
\text { GOOD-NEIGHBORLY RELATIONS } \\
\text { KA6 }\end{array}$} & KA6.1-Spaces equipped for gatherings, meetings, joint activities, and games \\
\hline & KA6.2-Communication with the neighbors \\
\hline & KA6.3-Frequency of using POSs \\
\hline & KA6.4-Structure of users - different age groups of the residents \\
\hline & $\begin{array}{l}\text { KA6.5-Participation of the residents in the spatial organization and } \\
\text { maintenance of POS }\end{array}$ \\
\hline \multirow{5}{*}{$\begin{array}{l}\text { VISUAL AND ESTHETIC COMFORT } \\
\text { KA7 }\end{array}$} & KA7.1-Urban design \\
\hline & KA7.2-Spatial and ambient integrity and attractiveness of the space \\
\hline & KA7.3-Variety of content \\
\hline & KA7.4-Presence of natural elements \\
\hline & KA7.5-Anthropometric suitability \\
\hline \multirow{2}{*}{$\begin{array}{l}\text { MAINTENANCE } \\
\text { KA8 }\end{array}$} & KA8.1-Scheduled maintenance \\
\hline & KA8.2-Adaptation to the fluctuating demands of the residents \\
\hline
\end{tabular}


Visual and aesthetic comfort is analyzed through the general impression of the space, i.e., whether it provokes a sense of comfort or appears unattractive or unsafe to the residents, using the following indicators: quality of urban design, spatial and ambient integrity and attractiveness of the space, a variety of content, the presence of natural elements, and anthropometric suitability [44]. Finally, the study considers the aspect of maintenance and management, since only properly maintained POSs can be sustainable and fulfill multiple quality criteria in terms of the quality of life.

Detailed identification of the current state of POSs was conducted using direct field observation in April 2017. The survey of LHEs residents involved a questionnaire, which can be seen in Appendix A (Figure A1). It was developed according to the methodology for scientific surveys, using interviews and fill-in questionnaires during April 2017. The selection of respondents was based on a random sample of residents, while the survey sample included 70 respondents for each of the two areas, which depended on the residents' willingness to participate in the survey. The survey was conducted by examining residents of different ages, according to the following categories: a. children up to 18 years, b. 18-45 years, c. 45-65 years, d. over 65 years. A total of 140 residents were surveyed to determine their opinions on the spatial and functional, psychosocial, environmental, technological and organizational, and visual and aesthetic properties of POSs. One objective was to determine how frequently residents use POSs, in what types of POSs they spend most of their time, and why they use POSs. Regarding the psychosocial indicators, the residents were asked about their sense of safety, their relations with other users of the spaces, their interaction with their neighbors, and the willingness of spending time in POSs. The survey also encompassed the general evaluation of the current state of POSs, environmental comfort, and the visual and aesthetic perception of the residents. It was particularly important to identify the following indicators: residents' willingness to participate in POS regeneration; their participation in POS maintenance; their readiness to initiate regeneration; and in particular the identification of the key issues they had observed and of their needs, demands, and suggestions for improvement (Figure A1, Appendix A). Based on observation, residents' survey and case study characteristics and problems of POSs were identified, compared, and synthesized and the level of POSs deprivation was defined and is presented in Table 2.

Priority development goals for POS regeneration were established based on the identified problems in the case study and information about residents' needs and demands regarding POSs improvement obtained in residents' survey. The case study and defined development goals were finally used to set out the comprehensive set of development measures, sub-measures, and activities for POS regeneration towards sustainability. To examine the possibility of applying a defined set of measures in the current conditions in Nis, the planning documentation and the current financial, managerial, and organizational framework at the local level were analyzed and the development preconditions and guidelines for the implementation of the proposed set of measures were derived.

\subsection{Areas of Study}

The reason for selecting the chosen areas of study was linked to the key research questions. In this research, key features to guide the selection were the spatial and functional organization of POSs and location within the city of Nis as representative of the post-socialist city with inherited LHEs (Figure 1). The choice of research areas was also based on preliminary fieldwork and document analysis. We have chosen two representative areas within inherited LHEs for detailed analysis, based on previously defined criteria: 1. areas have a similar type of functional organization, morphology and architectural characteristics and period of development; 2 . areas have a different disposition in the structure of the urban matrix of the city of Nis, namely the first is located in the wider city center, and the second is located on the outskirts of the city; 3 . within the areas at least one rooftop extension and construction of a new residential building are present. In choosing the areas to compare it with, the logic of extreme cases has been applied [12]. It was based on the assumption that if various problems and a high level of devastation exist in extremes, it, will exist in all in-between cases-POSs in inherited LHEs at the local level (Figure 1). In this initial research, the basic idea was to investigate potentials for improvement of 
POSs in inherited LHEs in the immediate residential environment, to contextually frame the results of the study. Our findings are supposed to provide an adequate platform for further research that will consider not only that type of POSs but also the POS of residential complexes and zones.

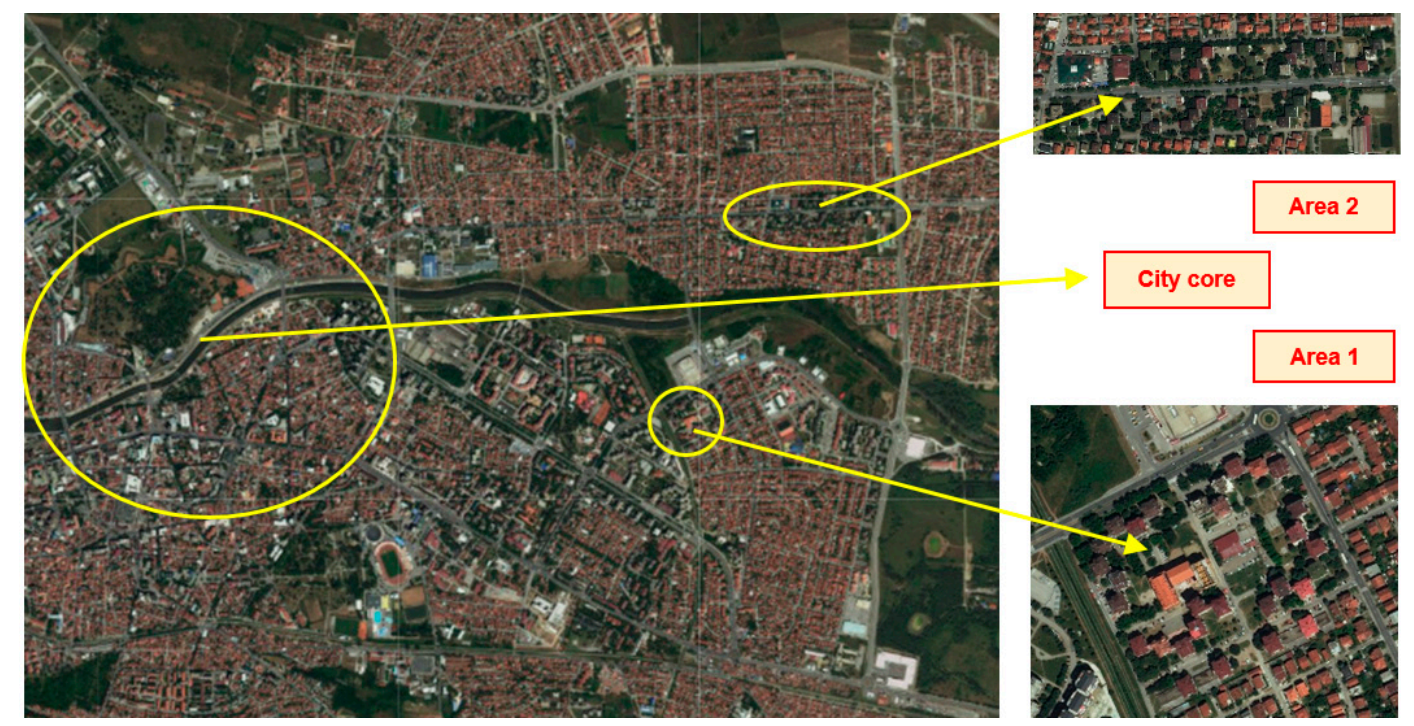

Figure 1. Study areas' positions within the city of Niš. Source: https://geosrbija.rs/.

\section{Case Studies of Selected Large Housing Estates in Niš}

\subsection{Niš-Urban Design Brief}

With a population of approximately 258,000 [68], the city of Niš is the second-largest city in Serbia and a post-socialist city. It is considered as an above-average developed city within Serbia. Regardless, Niš is going through a difficult period of recession and adverse economic circumstances, resulting from multiple sociopolitical and other changes at the turn of the 21st century. City development depends increasingly less on the country's economic status, and the consequences are noticeable among the considerable differences between the level of development of the capital and other Serbian cities. Due to significant changes during the 1990s, Niš, a mighty industrial center in the socialist period, was faced with the following adversities: restructuring of state-owned companies, substantial drop in production, and increased poverty due to dissolution and closure of state-owned companies. Besides, the urban matrix of Niš underwent several social and spatial changes. These changes also affected the state of LHEs, which comprise $30 \%$ of the housing stock in Niš [69], so their current state poses a serious problem. The negative effects of the said changes also include dilapidated POSs within LHEs in Niš, which manifest unfavorably on quality of life.

The trends of LHE construction in Niš are similar to other former socialist cities, where urban planning was an important instrument for the dissemination of the socialist ideology [70], but also a response to the population rise after up to 1990. In response to the newly emerging housing demand, the state favored the construction of LHEs on the outskirts of cities, often in the vicinity of industrial buildings, which led to a substantial expansion of the built environment in Niš. One in every five apartment buildings was erected before 1960 [69], while the most extensive housing construction occurred between 1971 and 1981. The construction was financed from municipal and city funds, which were in turn financed from "contributions" by state-owned companies. The development land as well as the major portions of the housing stock were state-owned, while the city public utility companies were in charge of maintaining the apartment buildings and the POSs.

Similar to other Serbian cities, the LHEs in Niš were also comprehensively planned following the general urban plans and detailed plans for specific parts of the city. Entire residential parts of the city were developed for as many as 5000 to 10,000 residents. The most frequently used construction 
system was the open free blocks system, dominated by buildings with the GF+3 to GF+4 number of floors. The idea was to develop POSs between buildings to provide the residents with spaces for socializing and gathering and with a safe environment for children to play [71,72]. Many of these spaces represented the architectural qualities of the modernism of the second half of the 20th century [63]. However, it was most frequently the case that after the buildings had been constructed, there was not enough money for adequate equipment of POS. Consequently, many POSs became half-empty and unusable, which are their major challenges [13]. The formal revocation of ground rent, accompanied by the constant saving of resources, and the subsequent collapse of large construction companies due to economic crisis negatively affected the quality and state of POSs [40].

After 1990 and a series of socioeconomic, political, and institutional changes, over $98 \%$ of apartments in Niš became privately owned. One of the goals of privatization was to better manage and more efficiently maintain and renovate multistory buildings, a goal that remained unattainable even a decade after privatization. The high degree of poverty throughout the country contributed to the fact that the assets from the city, municipal, or state budgets allocated toward the state-owned companies (such as the public utility companies (PUCs) "Medijana" and "Gorica" in Niš) were never quite sufficient for preventive maintenance of POSs.

All of the above was reflected in the modality of POS transformations in the LHEs in the postsocialist period Nis. The types of transformations that have developed under the influence of economic, political, and spatial changes have been identified and considered in selected areas, and are assumed to be characteristic of other POS in inherited LHEs in Nis.

\subsection{Case Study 1}

This research area (A1) includes two housing blocks in the Krivi Vir residential area in the City Municipality of Medijana in Niš and it is presented in Figure 2. Krivi Vir residential area is the LHE with approximately 13,000 inhabitants. The housing blocks cover a surface area of 5.4 ha. The research area represents a variant configuration of blocks with the degraded linear shape of labels formed by an assembly of scattered-type units, designed as frame groupings. The LHE was built in the 1980s and it is a typical example of the large-scale housing estates of the time.

The number of floors ranges from GF +5 to GF +10 , with most buildings having rooftop extension units. In the area, there is also one restaurant and in the central part, a new residential building was constructed in 2017. The arrangement of the blocks reveals that their spatial organization is based on the principles of centrality and openness, which allows for the diversity of the POS configuration. Despite its potential in terms of spatial organization, size, and green open spaces, the area is an example of the considerably low quality of POSs. The equipment and usability of these spaces are modest, and the entire area is very poorly maintained, which is noticeable from the lacking or outdated urban equipment, few unusable playgrounds, dilapidated sporting grounds, and disorderly green spaces. Pedestrian paths are made of low-quality materials, which also applies to the sporting grounds and playgrounds. Dilapidation of POSs was also caused by rooftop extensions of apartment buildings and especially after the construction of a new building in a place where a public open space used to be, as they indirectly decreased the surface area of open and green spaces per resident through a dramatic upsurge of residents in the block. Simultaneously, there is an even more prominent issue of high-frequency parking on green surfaces and sidewalks (Figure 2). The low quality of POS has been noticed by the residents who participated in the survey. Only $21.84 \%$ used open spaces in front of their apartment buildings for everyday leisure, which suggests low usage. The survey also established that children were the majority of POS users $(41.38 \%)$, whereas other age groups were fairly equally distributed. The data indicate that the residents were dissatisfied with the current state of POSs or that they have not developed a habit of spending time in open spaces, as suggested by their evaluation of the current state of POSs (56\% thought that POSs were grossly neglected). The survey further determined that the residents gave the highest value to the POS activities of socializing with the neighbors $(23.98 \%)$ and relaxing $(22.81 \%)$. 
Environmental comfort of POSs is at a low level, as identified in Table 2 and stated by $74.71 \%$ of the residents. The reasons varied and included disorganized waste disposal areas, irregular maintenance of hygiene, and unmaintained green spaces-as confirmed by the survey: $50.98 \%$ of the residents thought that there were not enough green spaces and $81.25 \%$ were very dissatisfied with how they were maintained. Even though POS maintenance and regeneration are the duty of PUCs "Medijana" and "Gorica", the area has seen little activity from these companies. Maintenance of hygiene, green spaces, and street furniture is at a very low level. The reasons for reduced environmental comfort should also be sought in the construction of the new apartment building: a previously vacant space, which could have been converted into a mini park for the residents, was put to more profitable use.

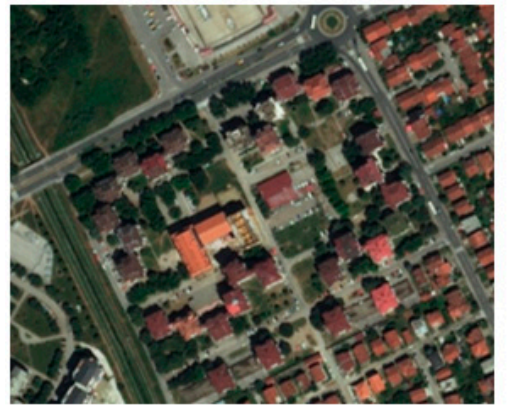

Site view, Source: https://a3.geosrbija.rs/

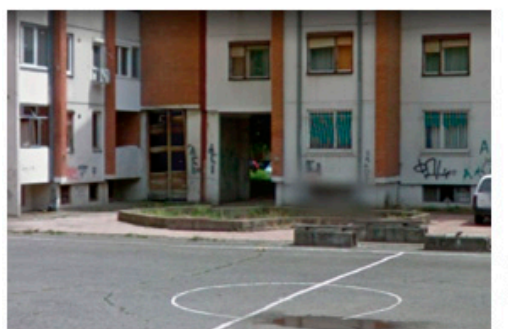

Site plan analysis-based on General Regulation Plan of Medijana municipality from 2015 \& Medijana Municipality

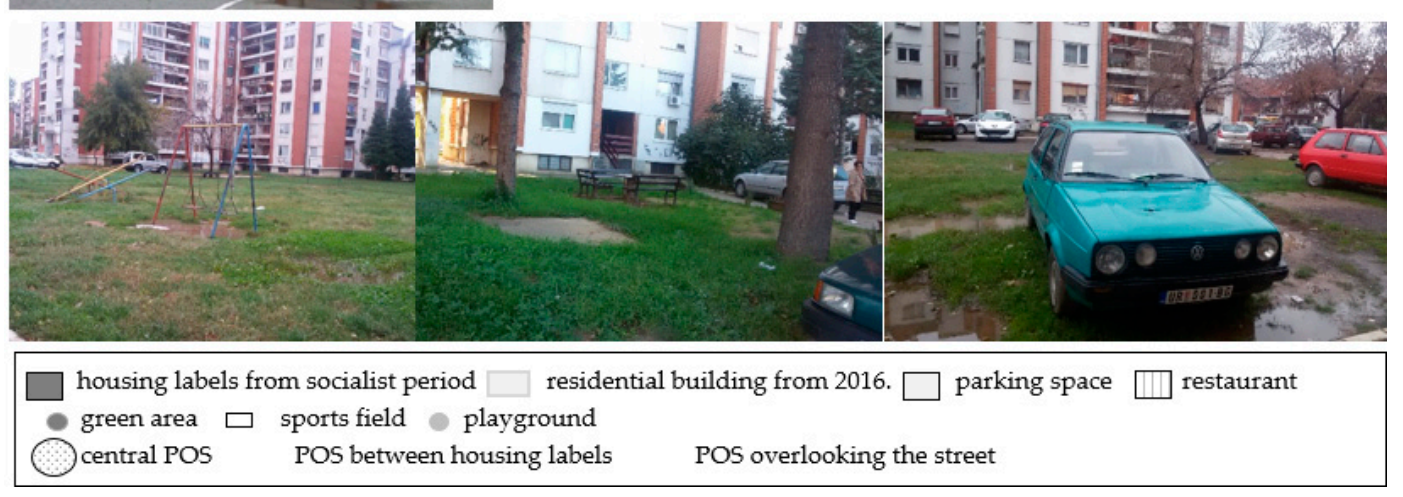

Figure 2. Analysis of a section of the Krivi Vir housing area. Photos by Ivana Bogdanović Protić.

The POSs in the area were considered unsafe according to both the author's and the residents' opinion (62.5\%). According to $52.83 \%$ of the residents, the chief reason was poor lighting, whereas $22.64 \%$ believed that vandalism was the main cause, which was confirmed by a field observation-broken benches, sports equipment, and playground sets (Figure 2, Table 2). The residents believed they did not have enough privacy in the area, which coincided with the author's observation (Table 2). According to the survey, only $36 \%$ of the residents interacted with other residents while using POS. Likewise, $64 \%$ thought that the area lacked properly organized spaces for interaction with neighbors, which is one of the key issues. Aesthetically, $80.46 \%$ of the residents considered open spaces unattractive, which, together with other issues, caused the low frequency of POS use.

Despite the dissatisfaction with the current state of POSs, $71.26 \%$ stated that they had never participated in POS maintenance, indicating a low level of self-organization. There were occasional 
instances of modest personalization, but these generally involved setting poor tables and chairs. Two core issues are causing the inefficient management and maintenance of POSs: (1) deficient legislation and (2) inefficient enforcement of laws due to deficient by-laws and institutional support. Furthermore, there is an evident confusion as to who is in charge of POS maintenance, since the authority is practically passed on to the owners of apartments in multistory buildings, even though they only own the land on which the building was erected, while the spaces surrounding the building are owned by the local self-government. It is somewhat encouraging that only $6.3 \%$ were prepared to participate financially in the regeneration, owing to the generally lowered social and economic status of the citizens of Niš. As many as $62.07 \%$ of the residents believed that a regeneration program should be initiated by both the residents and the professionals. It is devastating that $50.57 \%$ did not think that their suggestions regarding POS regeneration would be acknowledged, which highlights how important it is to promote the participative approach and how crucial it is for the local authorities to trust the residents through the instruments listed in the proposed set of regeneration measures.

\subsection{Case Study 2}

This research area (A2) is situated in the Durlan residential area in the City Municipality of Pantelej and it is presented in Figure 3. This housing area was developed on the outskirts of Niš in the 1970s and is dominated by single-family houses. The chosen research consists of five blocks with high rise housing built in the 1970s as a monofunctional housing area (the number of floors in the buildings is $\mathrm{GF}+4$ and GF+4+(Lo). The construction of the housing blocks was induced by a surge of new residents migrating from rural areas during the period of the postwar industrial bloom, indicating that the housing was intended for the working class. The observed area covers a surface of 8.4 ha.

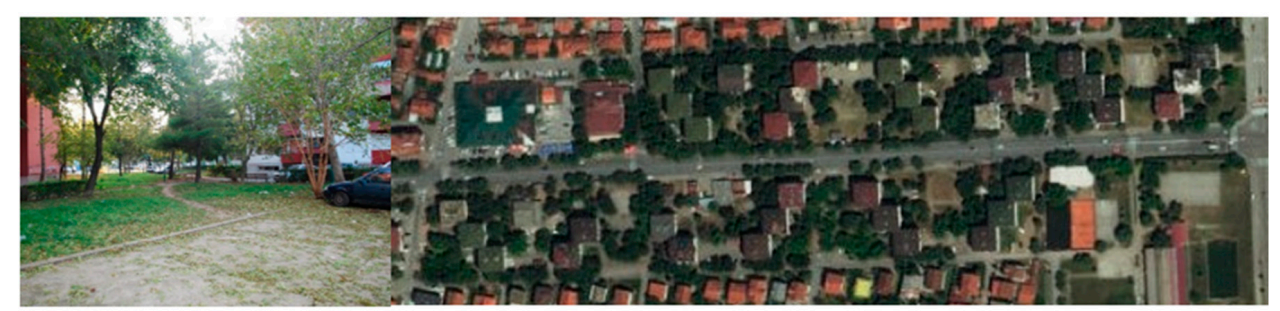

Site view, Source: https://a3.geosrbija.rs/

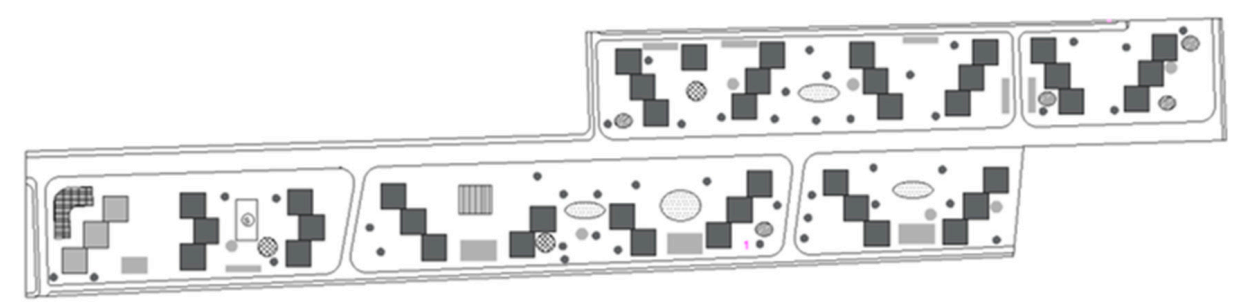

Site plan analysis-based on General Regulation Plan of Pantelej municipality from 2012 \& Pantelej Municipality, Cadastral Parcels

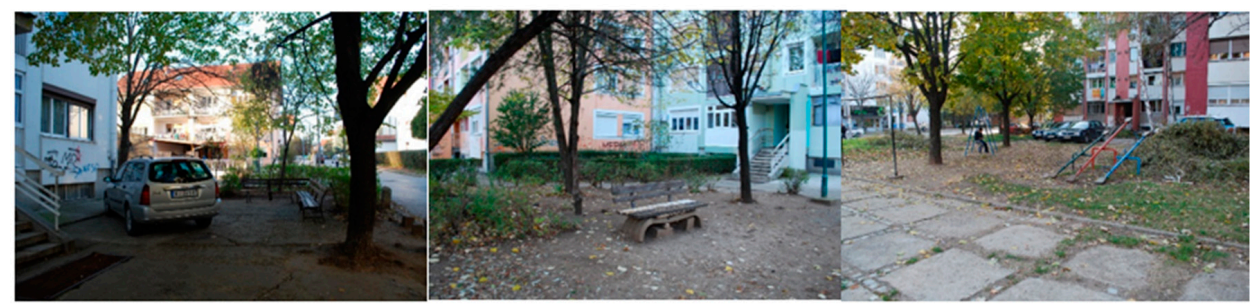

$\square$ housing labels from socialist period $\square$ residential building from 2001. $\square$ parking space $\square$ Municipality
green area $\square$ sports field playground
central POS POS between housing labels $\square$ POS overlooking the street

Figure 3. Analysis of a section of the Durlan housing area. Photos by Ivana Bogdanović Protić. 
Despite the great potential in terms of spatial organization, size, and green spaces, the POSs in this area are of inferior quality. The equipment of the POSs is very modest and devastated and the entire area is poorly maintained. This is evident from the lack of urban equipment or the visible wear of the existing one, few playgrounds completely out of use, neglected sporting grounds, and disorderly green spaces. Pedestrian paths are damaged and there are a lot of holes present. After the rooftop extensions on most of the buildings, the area saw a population surge and the overburdening of existing POSs. Simultaneously, there was an even more prominent issue of reduced parking space and consequent high-frequency parking on green surfaces (Table 2). Therefore, the usability of POSs is very low, as it has been confirmed by the residents participating in the survey.

Waste disposal units are not well-organized and are situated within the POSs (Figure 3). Hygiene is at a very low level as a result of littering outside the dumpsters by the residents themselves and of irregular or belated waste collection by the designated public utility company. This negatively affects the ecological comfort, on which as many as $84.51 \%$ of the residents agreed, while $87 \%$ thought that there are were green spaces but that their maintenance was inadequate. Even though one of the development goals stated in the City of Nis Development Strategy [73] was to expand and develop public and green open spaces, in this area it has not been the case. One of the priorities of this strategy is the Program of Inter-block Green Space Organization, which is implemented by PUC "Gorica", and it has proven inefficient primarily due to a lack of funds from the city budget for its implementation.

This research area is situated in the residential part of the city built in the period of flourishing Niš industry giants when apartments were given to their employees. The drawbacks of privatization were especially prominent in their case. The residents who lost their job due to the dissolution of the large industries in which they worked were now the owners of the apartments, without the option of investing in POS maintenance. It is devastating to learn that only $33.8 \%$ of the residents participated in POS maintenance and that only $9.58 \%$ were interested in participating in a future POS regeneration program. As many as $52.06 \%$ of the residents thought that a regeneration program should be initiated by both the residents and the professionals. It is concerning that as few as $50.57 \%$ expressed disbelief that their suggestions regarding POS regeneration would be acknowledged during the development of a POS regeneration program. Similar to Area 1, it is of paramount importance for the local authorities to promote the participative approach and to expand efforts to educate them.

\section{Discussion}

Based on the observation, interviews of residents of selected areas, and case studies, and according to the baseline criteria given in Table 1, the evaluation of characteristics and problems of POSs in selected study areas A1 and A2 were performed. Further, after the evaluation of present problems, a comparative analysis of characteristics, problems, and assessment of the degree of deprivation of the analyzed POSs was executed, which is presented in Table 2. Conducting such comparative problem analysis, as well as considering the opinion of tenants on desirable modalities of POS improvement served as a basis for defining development goals of POS regeneration in the direction of sustainability.

As the analysis shows, the selected representative areas in Niš have revealed a high level of functional, social, aesthetic, and environmental degradation, and a consequent degradation of the quality of life. This is all in sharp contrast with the increasing importance of the city's development land and the improvement of POS quality, which should be prioritized at the local level.

This study has revealed a high level of neglect and disorganization of POSs and outdated or demolished urban equipment in both analyzed areas. POSs in Area 2 were the most degraded and contained almost no usable POSs due to flawed design and construction and due to an absence of any kind of investment in their maintenance. In contrast, Area 1 POSs were better designed and constructed, but they have also become impersonal and chaotic owing to improper maintenance and management. Most POSs are impersonal, monotonous, and disorganized, which in turn makes them confusingly uniform and unattractive for the residents to use them as presented in Table 2. 
The analyzed areas do contain spaces for various categories of residents, but they are seriously underequipped. Gathering spaces were modestly designed and built, while the many years of poor maintenance and almost no investment have led to their continuous degradation. Urban equipment, where there is any, is damaged, demolished, and below the minimum quantitative and qualitative requirements. Residents are thus deprived of spaces for relaxing, gathering, and socializing with their neighbors, which leads to social alienation. The lack of POSs for the gathering of youth often involves inappropriate behavior of young people, which causes the residents from other age groups to feel unsafe. This study has also shown that children's playgrounds are neglected, with broken urban equipment or with cars parked on top of them, and that they do not ensure the proper amount of safety (Table 2). Both analyzed areas displayed a lack of parking spaces and the illegitimate repurposing of POSs for parking, with the issue being more pronounced in Area 2. This is due to the inadequate management of stationary traffic as well as the disrupted system of values in terms of the 'low culture of parking', which is more than evident in the cars parked in green spaces, playgrounds, and gathering spaces.

Table 2. Comparative evaluation of the characteristics and problems of POSs in research areas A1 and A2. Source: Bogdanovic [13].

\begin{tabular}{|c|c|c|c|}
\hline KEY ASPECTS & SPECIFIC INDICATORS & A1 & A2 \\
\hline \multirow{10}{*}{ KA1 } & KA1.1 & ** & * \\
\hline & KA1.2 & ** & * \\
\hline & KA1.3 & * & * \\
\hline & KA1.4 & * & * \\
\hline & KA1.5 & *** & $* *$ \\
\hline & KA1.6 & $* *$ & ** \\
\hline & KA1.7 & * & $*$ \\
\hline & KA1.8 & ** & * \\
\hline & KA1.9 & ** & ** \\
\hline & KA1.10 & * & $*$ \\
\hline \multirow{4}{*}{$\mathrm{KA} 2$} & KA2.1 & * & * \\
\hline & KA2.2 & * & * \\
\hline & KA2.3 & * & * \\
\hline & KA2.4 & * & $*$ \\
\hline \multirow{2}{*}{ KA3 } & KA3.1 & * & * \\
\hline & KA3.2 & * & * \\
\hline \multirow{7}{*}{ KA4 } & KA4.1 & * & $*$ \\
\hline & KA4.2 & ** & ** \\
\hline & KA4.3 & * & $*$ \\
\hline & KA4.4 & * & * \\
\hline & KA4.5 & * & * \\
\hline & KA4.6 & * & * \\
\hline & KA4.7 & * & * \\
\hline \multirow{7}{*}{ KA5 } & KA5.1 & * & * \\
\hline & KA5.2 & ** & * \\
\hline & KA5.3 & ** & * \\
\hline & KA5.4 & ** & ** \\
\hline & KA5.5 & ** & * \\
\hline & KA5.6 & * & * \\
\hline & KA5.7 & ** & ** \\
\hline \multirow{5}{*}{ KA6 } & KA6.1 & * & * \\
\hline & KA6.2 & ** & ** \\
\hline & KA6.3 & * & * \\
\hline & KA6.4 & ** & * \\
\hline & KA6.5 & $* *$ & * \\
\hline \multirow{5}{*}{ KA7 } & KA7.1 & * & * \\
\hline & KA7.2 & * & * \\
\hline & KA7.3 & * & * \\
\hline & KA7.4 & ** & * \\
\hline & KA7.5 & $* * *$ & * \\
\hline \multirow{2}{*}{ KA8 } & KA8.1 & * & * \\
\hline & KA8.2 & * & * \\
\hline
\end{tabular}

The symbol * denotes insufficient or the absence of the given POS quality aspect, symbol ** indicates that the analyzed POS quality aspects are present but insufficiently prominent, symbol ${ }^{* * *}$ indicates a considerable presence of the analyzed POS quality aspect. 
Analysis of the current state of the environmental capability of POSs indicated the presence of unfavorable microclimate, low level of hygiene maintenance and neglect of POSs, lack of public waste bins and inadequate distribution of waste disposal locations, and a lack of green spaces (Table 2). The existing green spaces have been neglected, for which the responsibility is shared between the residents themselves and the companies in charge of green space maintenance. In addition to threatening the microclimate, these issues also affect the hygiene of the residential area, the residents' health, and the appearance of POSs, making them unattractive. Combined with the deficient landscaping design, the disorganized, disorienting, and monotonous appearance creates an unpleasant atmosphere for the residents.

Safety of POSs has diminished in both analyzed areas, especially in Area 2. It is reflected in inadequate lighting and poor visibility, as well as in other objective and subjective factors, due to POS anonymity, unattractiveness, neglect, and vandalism (Table 2). This study has found that the majority of POSs in both areas are ridden with various types of antisocial behavior. Therefore, instead of integrating the residents into their living spaces, these POSs often become hotspots of conflicts between different age groups. The quality of neighborly relations in terms of gatherings and socialization varies, whereby continual contacts between residents are relatively rare, primarily due to the state of POSs (Table 2). In most POSs, privacy and territoriality are at a low level. Elements of POSs improvement and residents' personalization only include simple partial interventions.

POS degradation and considerably low quality are among other things caused by poor maintenance systems and insufficient financial investment in POSs. They are also caused by the inherited habits from the socialist period, unresolved ownership of the land, and unclearly defined authority for maintenance. It should be emphasized that the residents who litter within POSs and who generally lack a sense of responsibility for POS maintenance bear some degree of responsibility for the hygienic and environmental state of POSs. This research has determined that even though resident participation is considered a priority, the analysis of representative areas has shown that it rarely occurs in practice. The reasons primarily include the lack of interest from local authorities and housing companies/associations, but also by the residents themselves. The research has revealed the unwillingness of the residents to participate in POS maintenance or their unawareness of having every right to contribute to the organization of their housing environment. The residents also expressed considerable doubt that their participation will contribute to the final decisions regarding POS improvement.

Given the aforementioned problems, as well as interviews of tenants and consideration of their needs and proposals related to the regeneration of POSs, the following development goals of regeneration of POSs have been defined, which are similar for both analyzed areas: improvement of functional values and creation of flexible and multipurpose free spaces for different age categories of tenants, equipped with adequate urban equipment; application of the principles of modern urban design in the direction of creating attractive environments for tenants; introduction of public-private delineation; establishing standards for quality and maintenance of free spaces in the function of improving environmental quality; improvement of maintenance and management systems and modalities; solving parking problems; prevention of antisocial behavior and improvement of security; encouraging the personalization of tenants and promoting good neighborly relations.

Based on the case studies and following the particularities of the defined goals, it was determined that for a comprehensive treatment of the problem and fulfillment of the set goals, it is necessary to define a comprehensive set of improvement measures, which have been grouped into the following categories: spatial and functional (M1), environmental (M2), psychosocial (M3), visual and aesthetic (M4), and technological and organizational (M5) as presented in Tables 3-5. The general idea of the proposed set of regeneration measures is to transform and modernize POSs following the residents' needs, whereby it is imperative to remodel the existing POSs by using the principles of diversity, flexibility, and multifunctionality. For each of these categories of measures, key sub-measures have been defined, relevant for solving the identified problems in the chosen areas A1 and A2. 
Within the spatial and functional measures (Table 3) the following key sub-measures have been identified: 1 . use of variable and flexible urban design compatible with all age groups, 2 . possibility to personalize POSs through flexible design, 3. improving parking spaces, 4. separation of pedestrian and motor vehicle traffic. As presented in Table 3, proposed environmental measures are: 1. lighting, ventilation, and thermal comfort; 2 . reduction of urban noise; 3 . planned landscaping; 4 . use of renewable, environmentally friendly, and safe materials for urban equipment and pavements; 5. positioning of parking spaces further away from POSs; 6 . scheduled hygiene maintenance. A set of possible activities have defined for each of the identified sub-measures, and it is expected that after their application, regeneration of POSs in inherited LHEs could be possible. These activities are presented in Tables 3-5.

Table 3. Possible spatial and functional and environmental measures, sub-measures, and activities within the POS regeneration. Source: Bogdanovic [13].

\begin{tabular}{|c|c|}
\hline & MEASURES, SUB-MEASURES, AND ACTIVITIES \\
\hline \multirow{8}{*}{$\bar{\Sigma}$} & M1.1. Use of variable and flexible urban design compatible with all age groups \\
\hline & $\begin{array}{l}\text { - Providing various types of POSs with as many natural elements as possible that will stimulate children's play, } \\
\text { - } \quad \text { Preativity, and imagination } \\
\text { - } \text { (active and passive recreation) without disrupting their privacy near the housing units } \\
\text { - } \quad \text { Seveloping diverse physically and hygienically safe recreational spaces for different age groups } \\
\text { - } \quad \text { Spatial organization for the gathering of youth } \\
\text { - } \quad \text { Using large POSs for active recreation } \\
\text { - Spatial organization for children's play } \\
\text { - } \quad \text { Modern landscaping of POSs with designated spaces for parents to sit, monitor their children, and socialize } \\
\text { - Providing common areas for informal or formal games and gatherings } \\
\text { - } \quad \text { Providing active spaces that offer flexibility for organized or spontaneous activities }\end{array}$ \\
\hline & M1.2. Encouraging possibility to personalize POSs through flexible design \\
\hline & $\begin{array}{l}\text { - Designing a website for residents' ideas about the personalization of POS } \\
\text { - } \quad \text { Promoting community gardening }\end{array}$ \\
\hline & M1.3. Improving parking spaces \\
\hline & $\begin{array}{ll}\text { - } & \text { Building above ground and underground garages } \\
\text { - } & \text { Planning for new parking spaces over a portion of green spaces or the surrounding public land } \\
\text { - } & \text { Introducing penalties for parking in POSs and green spaces }\end{array}$ \\
\hline & M1.4. Separation of pedestrian and motor vehicle traffic \\
\hline & $\begin{array}{l}\text { - } \quad \text { Improving the legibility of pedestrian paths within POSs } \\
\text { - } \quad \text { Restricting public circulation through semi-public/semi-private spaces } \\
\text { - } \quad \text { Enabling direct pedestrian access to the building entrance from POSs } \\
\text { - } \quad \text { Forming a buffer zone between public walkways and housing units } \\
\text { - }\end{array}$ \\
\hline \multirow{10}{*}{$\tilde{\Sigma}$} & M2.1. Lighting, ventilation, and thermal comfort \\
\hline & $\begin{array}{l}\text { - } \quad \text { Planning for covered spaces, awnings, and pergolas, weather-adjustable if possible } \\
\text { - } \quad \text { Using materials that have a cooling effect in the summer (additional green spaces) } \\
\text { - } \quad \text { Planting more tall trees to create a natural surrounding and shade }\end{array}$ \\
\hline & M2.2. Reduction of urban noise \\
\hline & $\begin{array}{l}\text { - } \quad \text { Adjusting the position of recreational grounds and noisy activities to the building position } \\
\text { - } \quad \text { Planning for isolated and more intimate spaces for private time or relaxation } \\
\text { - } \quad \text { Prohibiting noisy activities during specified times of day and night }\end{array}$ \\
\hline & M2.3. Planned landscaping \\
\hline & $\begin{array}{ll}\text { - } & \text { Adding green spaces } \\
\text { - } & \text { Continuously maintaining green spaces } \\
\text { - } & \text { Introducing penalties for littering on green spaces } \\
\text { - } & \text { Introducing penalties for parking on green spaces } \\
\text { - } & \text { Encouraging the development of community gardens } \\
\end{array}$ \\
\hline & M2.4. Use of renewable, environmentally friendly, and safe materials for urban equipment and pavements \\
\hline & M2.5. The positioning of parking spaces further away from POSs \\
\hline & M2.6. Scheduled hygiene maintenance \\
\hline & $\begin{array}{l}\text { - Organizing waste disposal locations within confined spaces outside POSs } \\
\text { - Organizing scheduled waste collection and cleaning of POSs and green spaces }\end{array}$ \\
\hline
\end{tabular}


Further, within the psychosocial measures (Table 4), the following key sub-measures have been defined: 1 . improvement of safety and security for the residents; 2 . design of a strategy for prevention and elimination of antisocial behavior; 3 . creation of defendable spaces with clear boundaries and good visibility, and introduction of public/private delineation; 4 . encouragement and strengthening of a sense of community and comfort in POS. The key sub-measures within visual and aesthetic measures is the achievement of visual and aesthetic comfort, as presented in Table 4.

Table 4. Possible psychosocial and visual and aesthetic measures, sub-measures, and activities within the POS regeneration. Source: Bogdanovic [13].

\begin{tabular}{|c|c|}
\hline & MEASURES, SUB-MEASURES, AND ACTIVITIES \\
\hline \multirow{7}{*}{$\sum_{\Sigma}^{m}$} & aprovement of safety and security for the residents \\
\hline & $\begin{array}{l}\text { - } \quad \text { Greater possibility of POS surveillance; installing cameras } \\
\text { - } \quad \text { Providing controlled access by clearly separating pedestrian from motor vehicle traffic and } \\
\text { through the legible and direct circulation } \\
\text { - } \quad \text { Placing playgrounds closer to the apartment buildings to facilitate parental supervision } \\
\text { - Improving POS lighting } \\
\text { - Introducing scheduled hygiene maintenance } \\
\text { - Introducing scheduled urban equipment maintenance }\end{array}$ \\
\hline & M3.2. Design of a strategy for prevention and elimination of antisocial behavior \\
\hline & $\begin{array}{l}\text { M3.3. Creation of defendable spaces with clear boundaries and good visibility, and } \\
\text { introduction of public/private sector delineation }\end{array}$ \\
\hline & $\begin{array}{l}\text { - Introducing flexible boundaries between different categories of POSs to facilitate control, } \\
\text { supervision, and territoriality } \\
\text { - Spatially organizing vacant POSs to prevent them from becoming hotspots of } \\
\text { antisocial behavior } \\
\text { Implementing attractive urban design to positively influence the residents and lower the } \\
\text { probability of vandalism } \\
\text { - Strengthening the sense of community and belonging through the promotion of participation } \\
\text { in POS maintenance, organization, and regeneration programs } \\
\text { Improving the management and maintenance system }\end{array}$ \\
\hline & M3.4. Encouragement and strengthening of a sense of community and comfort in POS \\
\hline & $\begin{array}{l}\text { - Designing common-area POSs that will invite residents and encourage them to spend time in } \\
\text { POSs-easily accessible spaces in well-suited locations enabling residents to relax and engage } \\
\text { in informal social interactions } \\
\text { - Socio-cultural entertainment-organizing spaces that stimulate group activities } \\
\text { - Digital base-creating virtual networks of the residential community-community profile, } \\
\text { invitations to other communities, digital surveillance, dissemination of information to } \\
\text { the neighbors } \\
\text { - Encouraging community gardening } \\
\text { - Stimulating competences between POSs in different blocks, neighborhoods, and complexes }\end{array}$ \\
\hline \multirow[b]{2}{*}{$\sum^{J}$} & M4.1. Achievement of visual and esthetic comfort \\
\hline & $\begin{array}{l}\text { - } \quad \text { Using modern principles of urban design to create more attractive spaces } \\
\text { - } \quad \text { Introducing natural elements } \\
\text { - } \quad \text { Introducing landscaping elements } \\
\text { - } \quad \text { Maintaining spatial and ambient integrity } \\
\text { - } \quad \text { Creating spaces according to the measure of the man }\end{array}$ \\
\hline
\end{tabular}


Finally, within the technological and organizational measures, the following key sub-measures have been identified: 1 . reorganization and modernization of the maintenance and management system, 2. resolution of the ownership status, 3. facilitation of the establishment of residents' association, 4. improvement of the cooperation between local authorities and residents' associations, 5. encouragement of residents participation, 6. provision of financial instruments, as it can be seen in Table 5 .

Table 5. Possible technological and organizational measures, sub-measures, and activities within the POS regeneration for Areas 1 and 2. Source: Bogdanovic [13].

\begin{tabular}{l} 
MEASURES, SUB-MEASURES, AND ACTIVITIES \\
\hline M5.1. Reorganization and modernization of the maintenance and management system \\
\hline - $\quad$ Restructuring, modernizing, and strengthening the public utility companies "Medijana" and \\
"Gorica", in charge of maintenance, and providing incentives for the founding of \\
private companies \\
- $\quad$ Spatially organizing POSs to facilitate maintenance \\
Introducing scheduled maintenance after the regeneration to ensure the sustainability of the \\
implemented measures \\
$\quad$ Supervising POS usage and the application of principles of successful urban design; it would be \\
beneficial to perform a study by mapping usage and activities and by asking the residents if they \\
are satisfied with how POSs were improved \\
\hline M5.2. Resolution of the ownership status \\
\hline M5.3. Factilitation of the establishment of residents' associations \\
\hline - $\quad$ Organizing training for resident participation \\
Founding local offices to be in charge of the regeneration of POSs within LHEs in the city \\
municipalities of Medijana (Area 1) and Pantelej (Area 2) \\
Encouraging long-term POS management and promotion of successful POSs in terms of spatial \\
organization and maintenance
\end{tabular}


We expect that the implementation of the proposed set of measures, sub-measures, and activities would restore the attractiveness of LHEs, humanize the residential environment, and promote the fundamental living values of POSs, following the set quality criteria of POSs in Table 1. Concerning the established quality criteria of POSs based on which the evaluation of selected POSs was performed, the analysis showed that the primary key measures and sub-measures to improve usability, diversity, and accessibility are: 1 . use of variable and flexible urban design compatible with all age groups and 2. separation of pedestrian and motor vehicle traffic, as presented in Table 6.

Table 6. Correlation of key sub-measures and key aspects of quality of POSs within the POS regeneration Source: authors.

\begin{tabular}{|c|c|}
\hline KEY ASPECTS & KEY SUB-MEASURES \\
\hline KA1 & M1.1; M1.4 \\
\hline KA2 & M1.1; M4.1 \\
\hline KA3 & M2.1; M2.3 \\
\hline KA4 & M1.4; M3.1; M3.2 \\
\hline KA5 & M1.2; M2.2 \\
\hline KA6 & M1.2; M3.4 \\
\hline KA7 & M2.3; M4.1 \\
\hline KA8 & M5.1; M5.5 \\
\hline
\end{tabular}

Concerning the second quality criterion—urban design—primary key measures and sub-measures are: 1. use of variable and flexible urban design compatible with all age groups and 2. achievement of visual and aesthetic comfort. Concerning the health and comfort criteria, primary key measures and sub-measures are: 1. lighting, ventilation, and thermal comfort and 2. landscape planning (Table 6). The analysis showed that the primary key measures and sub-measures for treating the problems with safety are: 1 . separation of pedestrian and motor vehicle traffic, 2 . improvement of safety and security for the residents, and 3. design of a strategy for prevention and elimination of antisocial behavior. In the aim of improving privacy and territoriality, the key measures and sub-measures are the following: 1. encouraging possibility to personalize POSs through flexible design and 2. reduction of urban noise. Concerning the social interaction and good neighborly relations factor, primary key measures and sub-measures are: 1 . encouraging possibility to personalize POSs through flexible design and 2. encouragement and strengthening of a sense of community and comfort in POSs. In the aim of visual and aesthetic comfort, primary key measures and sub-measures are. 1. planned landscaping and 2. achievement of visual and aesthetic comfort. Finally, concerning the last quality aspect-maintenance-key measures and sub-measures are: 1 reorganization and modernization of the maintenance and management system and 2. encouragement of resident participation (Table 6).

For successful regeneration of POSs and realization of established quality aspects following the residents' needs and demands, simultaneous application of all the above measures is necessary, in the direction of achieving the sustainability of POSs.

Given the high diversity of problems of POSs in the analyzed areas, as well as current local and planning regulations, local actors in the field of maintenance and management of POS, the research has revealed the causes of such a high level of degradation of POSs to be found among a variety of factors: unplanned design of POSs in the construction phase; noninvestment in maintenance in the socialist period, which continued in the post-socialist period; a general increase in antisocial behavior in POSs; inefficient institutional and organizational frameworks for maintenance and management after the privatization of buildings in inherited LHEs, the weak interest of political actors and local authorities in improving POSs; modest economic opportunities for local authorities to improve POSs; 
noncompliance with participatory planning in our planning regulations; nonexistence of planning and urban and housing policy and inadequate treatment of POS in laws, regulations, and standards. Based on the above facts, it is conducted that it is not possible to apply the proposed measures in the current local planning regulations and with the local organizational and economic circumstances in Nis.

\section{Conclusions}

Concerning the first research aim-to investigate whether there is a relationship between the transformation flows of POSs in inherited LHEs and degradation and what are the types of that changes of POSs-the conducted research has indicated that this relationship exists in the following: POSs in inherited LHEs changed during the post-socialist period following the transformations of the LHEs within which they were built and under the influence of multiple spatial, socioeconomic, and institutional changes. Partial interventions in LHEs are typical of post-socialist Serbia, which is reflected in the treatment and the current state of POSs. One of the key findings of this study was that all the aforementioned transformations negatively affected the state of POSs in inherited LHEs, and the generalization of the findings refers to the lasting deterioration and the absence of basic human values. Even though the proper management, maintenance, and improvement of the POSs inherited LHEs and is well known, the present study showed fully opposite tendencies in the representative examples of POSs within LHEs. Despite the extensive significance of POSs for the quality of life of residents, a comparative analysis of two case studies of representative POSs in inherited LHEs revealed the following: (1) in the socialist period, POSs were treated and designed without adherence to any standard and with minimum expenditure; (2) spatial and functional, environmental, social, and aesthetic values of POSs were degraded due to prolonged continuous neglect, both in terms of planning and legislation and in terms of maintenance; (3) the trend of POS degradation is ongoing and POSs are still characterized by a high degree of dilapidation. Generally, POSs represent the unused potential of the LHEs, as they are often used as sites for new housing development, illegal car parking, or household waste disposal, resulting in neglected, unsafe, and unattractive spaces. This was corroborated by the observed frequency of POS utilization by the residents, which was fairly low. All these issues add to the risk of increased reduction of the residents' quality of life.

Concerning the second research aim — to invest whether it is possible to define development measures for the regeneration of POSs towards sustainability through observation, survey, and case study analysis-we can conclude that it is possible to define development measures for POSs regeneration.

Concerning the second research aim-to investigate whether it is possible to define long-term development measures for the regeneration of POSs and what the types of that measures are-we can conclude that it is possible to define development measures for POSs regeneration.

The study indicated that it is necessary to move beyond the narrow interpretation and to adopt a comprehensive viewpoint that can take into account the complexity of problems of POSs while considering the institutional, social, and urban post-socialist transformations in the LHEs in which they were built. The research conducted here has pointed out that the wide range of problems identified at POSs and the high degree of their deprivation should be treated with comprehensive long-term measures. Following that, the following categories of measures have been proposed: spatial and functional, psychosocial, environmental, technological and organizational, and visual and aesthetic. Among the proposed measures, the following are the most prominent: POS improvement towards creating multipurpose spaces for different age groups of residents, application of the principles of modern urban design adjusted to the limited financial resources, resolution of the parking issue, encouragement of resident participation in POS organization and maintenance, promotion of community gardening, prevention of antisocial behavior and safety improvements, increased POS hygiene to improve environmental capability, improved maintenance and establishment of standards for quality and 
maintenance of POSs. The research has also indicated that only simultaneous implementation of this established set of measures could enable a long-term regeneration of POSs towards sustainability.

Concerning the third research aim-whether in the current local planning regulations and with the local organizational and economic circumstances in Nis it is possible to apply defined regeneration measures, what are the restrictions for their implementation, and what are the development requirements and guidelines for their efficient application - the research conducted here has indicated that this relationship exists in the following: there are currently no adequate institutional, legislative, and financial conditions to implement the proposed measures, primarily due to the outdated and inadequate legislation regarding housing and POSs (including POSs within LHEs) and the current way of treating POSs that prevails in our planning practice. In times of social and economic crisis in Serbia, the undefined national housing policy targeting the improvement of POSs in inherited LHEs and the lack of relevant standards and norms regarding the planned treatment of open spaces fundamentally restrict the implementation of the proposed comprehensive set of measures. Restrictions also include the insufficient institutional capacity to prepare and implement POS regeneration programs and projects, and in particular the absence of a financial framework and subsidies to help their implementation. Shaped by these circumstances, our research has indicated that a high degree of complexity of requirements that must be met to determine the necessary set of development preconditions and guidelines at the strategic and operational level, which would guide and enable conditions for effective application of defined measures of POSs in inherited LHEs in Nis. Therefore, this research proposes several institutional, organizational, and legal development prerequisites and guidelines as future preconditions for the creation of planning and programming conditions for efficient implementation of the proposed set of regeneration measures:

\section{- Prerequisite 1-transformation of the institutional and organizational framework}

The previous sections have shown that Niš has an unstable institutional framework, that there are only partial interventions concerning POS regeneration, and that obstacles are preventing the involvement of the civil and private sector. Possible guidelines for overcoming the mentioned obstacles are: new POS organization and improvement policy, the establishment of a partnership approach, and involvement of different entities in the planning, preparation, and implementation of the POS regeneration program. A key priority for the implementation of the POS regeneration measures is the expansion of institutional capacities. Since the local government has the preeminent authority to treat POSs in LHEs, it should increase the responsibility, dedication, and engagement of relevant institutions to increase their currently minimal interest and overcome the added financial issues and, in addition, introduce additional sectors, which would handle strategic initiatives of POS development. Cadastral surveys of POSs in LHEs and creating profiles of POSs in LHEs for the entire city is a possible and significant instrument for implementing the set of regeneration measures, as it would provide insight into the availability of POSs and serve as a basis for developing a strategy and a regeneration program according to priorities and depending on the degree of dilapidation $[13,65]$.

\section{- Prerequisite 2-establishment of public-private partnerships}

Under the conditions of a lasting economic crisis, the planned (in) activity regarding POS regeneration and the serious limitations to implementing the set of regeneration measures are the result of inefficient cooperation between various institutions, local authorities, and resident assemblies, as well as a lack of private investment in the organization of POSs. Thus, a possible suitable instrument for implementing the set of regeneration measures is to develop a better foundation for the establishment of public-private partnerships. This instrument is aimed toward creating a basis for increasing the diversity of ideas and the general potential in the planning regeneration measures, for communication and cooperation between stakeholders, and a dynamic balance between public and private interest. Additional measures include the diversification of necessary entities from the public and private sectors and the civil society, as well as their joint efforts to become included in the EU programs and to receive financial support. 


\section{- Prerequisite 3-encouragement of resident participation}

Given the low level of resident participation in the organization of POSs in Niš, as well as their general lack of interest in participating in improvement programs, it is of paramount importance to encourage them to participate. Possible instruments to encourage resident participation include the following:

- Informing the residents about the specific activities to improve POSs, educating them and training them to acquire the skills required for their participation;

- Promoting the attitude that all residents can participate in POSs regeneration/social inclusion

- Regeneration program transparency_providing the residents with clear information about the potential of POSs and realistic changes and the requirements for their engagement;

- Facilitating a dialogue between the residents and relevant entities through consultations or partnerships with direct residents' involvement in decision-making;

- Organizing training for local authorities' personnel who will coordinate the necessary activities in the regeneration program and help include the residents in all stages of the program;

- Accepting and encouraging residents' initiatives and encouraging the development of community gardens, yard maintenance, joint POS management, and regeneration of vacant POSs;

\section{- Prerequisite 4-provision of adequate financial instruments}

Since only $2 \%$ of the local budget is currently allocated for sport and recreation, and only a portion of it goes towards POS organization and maintenance, one of the most important instruments that would allow the implementation of the set of regeneration measures is to increase the funding for POS regeneration from the local budget. The key instrument for POS regeneration in Niš is to create the possibility of receiving subsidies from the state authorities and EU funds. The most important measure to obtain financial resources is to apply for donations from EU funds through various partnership programs. That is why the key instrument for the implementation is to introduce public-private partnerships to obtain the necessary funding. Special focus should be placed on encouraging private companies to offer to finance, through proper regulatory measures.

\section{- Prerequisite 5-redefinition of planning and urban and housing policy}

The transformation of the socialist political and social order and the privatization of the bulk of the public housing stock were accompanied by a general disregard for urban planning and a lack of adequate urban and housing policy for inherited LHEs and the improvement of existing POSs. Consequently, the considerable significance is the improvement of the POS planning system and the introduction of an integrated approach to POS regeneration, which would involve a systematic and comprehensive treatment and harmonization of planning documentation on different levels. It would be equally important to initiate the regeneration programs as the priority of the Housing Strategy of the City of Niš [74] and local development strategy, which would define a clear vision of POS improvement in inherited LHEs as the primary strategic goal.

\section{- Prerequisite 6-updates of laws, regulations, and standards}

Since no laws are regulating POS organization in Niš and Serbia, there are also no explicit regulations except for the municipal decisions that define "green and open spaces". The organization, planning, and regeneration of POSs is impossible without the existence of proper standards and norms and possible instruments for implementing the set of regeneration measures include adopting general quality indicators of POSs in inherited LHEs, whereby the most important are: (1) POS area per capita according to the type of open space, (2) minimum requirements for equipping POS for different categories of residents, and (3) area of green space per capita for everyday rest and recreation. To enable the implementation of the set of regeneration measures, it is also important to establish the typology 
of POSs in inherited LHEs and quality aspects (according to Table 2), which would subsequently be used to (1) identify the degree of dilapidation, (2) devise a basic regeneration plan according to the priorities, and (3) steer the development of POSs according to the defined criteria of quality. Special effort is needed for the establishment of a public/private space delineation with clearly prescribed rights and obligations of owners, authorization for maintenance, and types of activities and with the possibility of access.

This study was conducted on two representative study areas in LHEs in Niš inherited from the socialist period, and the generalization of the study results on the course of degradation, problem categories, and identified measures and activities can be used as a framework for a more comprehensive examination of the possibilities of regenerating POSs in inherited LHEs for the city level, which would include not only POSs in the immediate residential area but also other types of POSs in LHEs. Other directions of more comprehensive future research might include (1) the identification of the current state and degree of dilapidation of POSs in inherited LHEs at the local level, (2) the systematization of identified POSs according to their degree of dilapidation, and (3) the determination of priority areas requiring immediate interventions. This could be the basis for creating a long-term strategy for POS regeneration towards LHEs' sustainability in Niš. The development of institutional, organizational, and legal guidelines that were elaborated could serve as future preconditions for the effective implementation of the established set of regeneration measures, which could be applied in other Serbian cities. This paper is initial research with a focus on the identification of improvement measures and can be a starting point for creating regeneration strategies for POSs and identifying driving forces for measures and activities implementation, which can be examined in some of the further research. Furthermore, the established set of measures can serve as a basis for creating a model option for improving POSs in other post-socialist countries with similar problems, socioeconomic contexts, and planning, institutional, and legislative obstacles with prior consideration of their incorporation into their planning documentation.

Author Contributions: Conceptualization, I.B.P. and L.V.; formal analysis, I.B.P.; investigation, I.B.P.; methodology, I.B.P.; supervision, P.M.; visualization, I.B.P.; writing—original draft, I.B.P.; writing-review and editing, I.B.P., P.M., and L.V. All authors have read and agreed to the published version of the manuscript.

Funding: This research received no external funding.

Acknowledgments: The article was realized as part of the project "Optimization of architectural and urban planning and design in the function of sustainable development in Serbia" (TR-36042) financed by the Ministry of Education and Science of the Republic of Serbia within the framework of technological development research for the period 2011-2020.

Conflicts of Interest: The authors declare no conflict of interest. 
3. Power, A. Estates on the Edge: The Social Consequences of Mass Housing in Europe; Macmillan: London, UK, 1997.

4. Hall, S.; Murie, A.; Knorr-Siedow, T. Large housing estates in their historical context. In Restructuring Large Housing Estates in Europe; Hall, S., van Kempen, R., Dekker, K., Tosics, I., Eds.; Restructuring and Resistance Inside the Welfare Industry; Bristol University Press: Bristol, UK, 2005; pp. 63-84.

5. Murie, A.; van Kempen, R. Large Housing Estates, Policy Interventions and the implications for policy transfer. In Mass Housing in Europe: Multiple Faces of Development, Change and Response; Rowlands, R., Musterd, S., van Kempen, R., Eds.; Palgrave Macmillan: London, UK, 2009; pp. 191-212.

6. Musterd, S.; Ronald, V.K. Trapped or on the springboard? Housing careers in large housing estates in European cities. J. Urban Aff. 2007, 29, 311-329. [CrossRef]

7. Kovács, Z.; Herfert, G. Development pathways of large housing estates in post-socialist cities: An international comparison. Hous. Stud. 2012, 27, 324-342. [CrossRef]

8. Bodnár, J. Fin de Millénaire Budapest: Metamorphoses of Urban Life; Globalization and Community; University of Minnesota Press: Minneapolis, MN, USA, 2001; Volume 8.

9. Vasilevska, L.; Zivkovic, J.; Vasilevska, M.; Lalovic, K. Revealing the relationship between city size and spatial transformation of large housing estates in post-socialist Serbia. J. Hous. Built Environ. 2020, 35, 1099-1121. [CrossRef]

10. Turkington, R.; Van Kempen, R.; Wassenberg, F. High-Rise Housing in Europe: Current Trends and Future Prospects; Delft University Press: Delft, The Netherlands, 2004.

11. Wassenberg, F. Beyond an Ugly Appearance: Understanding the Physical Designand Built Environment of Large Housing Estates. In Housing Estates in Europe: Poverty, Ethnic Segregation and Policy Challenges; Hess, D.B., Tammaru, T., van Ham, M., Eds.; Springer: Cham, Switzerland, 2018; pp. 35-57.

12. Gunko, M.; Bogacheva, P.; Medvedev, A.; Kashnitsky, I. Path-dependent development of mass housing in Moscow, Russia. In Housing Estates in Europe; Springer: Cham, Switzerland, 2018; pp. 289-311.

13. Bogdanović Protić, I. Definisanje Modela Revitalizacije Slobodnih Prostora Kompleksa sa Višespratnim Stanovanjem u Funkciji Unapređenja Kvaliteta Života. Ph.D. Thesis, University of Niš, Niš, Serbia, 2016.

14. Sendi, R.; Aalbers, M.; Trigueiro, M. Public space in large housing estates. In Mass Housing in Europe; Springer: Cham, Switzerland, 2009; pp. 131-156.

15. Treija, S.; Bratuškins, U.; Bondars, E. Green open space in large scale housing estates: A place for challenge. J. Archit. Urban. 2012, 36, 264-271. [CrossRef]

16. Klomp, B. Responsibility of owner-occupiers for the technical quality of their house. In Proceedings of the ENHR International Conference "Housing in an Expanding Europe: Theory, Policy, Participation and Implementation”, Ljubljana, Slovenia, 2-5 July 2006; Available online: https:/repository.tudelft.nl/islandora/ object/uuid:d36788af-3fd6-49bf-8217-beb91bb6c11e/datastream/OBJ (accessed on 18 April 2020).

17. Kährik, A.; Tammaru, T. Soviet prefabricated panel housing estates: Areas of continued social mix or decline? The case of Tallinn. Hous. Stud. 2010, 25, 201-219. [CrossRef]

18. Temelová, J.; Novák, J.; Ouředníček, M.; Puldová, P. Housing estates in the Czech Republic after socialism: Various trajectories and inner differentiation. Urban Stud. 2011, 48, 1811-1834. [CrossRef]

19. Vasilevska, L.; Vranic, P.; Marinkovic, A. The effects of changes to the post-socialist urban planning framework on public open spaces in multi-story housing areas: A view from Nis, Serbia. Cities 2014, 36, 83-92. [CrossRef]

20. Bogdanović Protić, I.; Igić, M.; Ljubenović, M.; Mitković, M. Possible directions for revitalization of open spaces in high-rise housing complexes. In Proceedings of the 1st International Conference on Urban Planning, Niš, Serbia, 18-19 November 2016; pp. 151-158.

21. Beckhoven, E.V.; Bolt, G.; van Kempen, R. Theories of neighborhood change and decline: Their significance for post-WWII large housing estates in European cities. In Mass Housing in Europe. Multiple Faces of Development, Change and Response; Rowlands, R., van Kempen, R., Eds.; Palgrave Macmillan: London, UK, 2009; pp. $20-50$.

22. Tosics, I. Large housing estates in the west and in the east: What can we learn? In Proceedings of the Keynote Presentation at the Conference Restructuring Large Housing Estates in Europe: Policies, Practices and Perspectives, Ljubljana, Slovenia, 19-21 May 2005; Available online: http://restate.geo.uu.nl/conference/ downloads.html (accessed on 6 May 2020).

23. Braubach, M. Residential conditions and their impact on residential environment satisfaction and health: Results of the WHO large analysis and review of European housing and health status (LARES) study. Int. J. Environ. Pollut. 2007, 30, 384-403. [CrossRef] 
24. Calthorpe, P. The Next American Metropolis: Ecology, Community, and the American Dream; Princeton Architectural Press: New York, NY, USA, 1993.

25. Beyond an Ugly Appearance: Understanding the Physical Designand Built Environment of Large Housing Estates. In Housing Estates in Europe: Poverty, Ethnic Segregation and Policy Challenges; Hess, D.B.; Tammaru, T.; van Ham, M. (Eds.) Springer: Cham, Switzerland, 2018; pp. 3-35.

26. Bâldea, M.; Dumitrescu, C. High-density forms in contemporary architecture. Acta Tech. Napoc. Civil Eng. Arch. 2012, 56, 175-185.

27. Andrews, K.D.; Sendi, R. Large housing estates in Slovenia: A framework for renewal. Eur. J. Hous. Policy 2001, 1, 233-255. [CrossRef]

28. Newman, O. Creating Defensible Space; Diane Publishing: Darby, PA, USA, 1996.

29. Economic Commission for Europe. Country Profiles on the Housing Sector: Serbia and Montenegro; United Nations: Geneva, Switzerland, 2006.

30. Country Profiles on the Housing Sector. Available online: https:/www.unece.org/fileadmin/DAM/hlm/ prgm/cph/countries/serbia\%20and\%20montenegro/CP\%20Serbia\%20\&MontenegroPub.pdf (accessed on 13 September 2020).

31. Stanilov, K. The Post-Socialist City: Urban Form and Space Transformations in Central and Eastern Europe after Socialism; Springer Science \& Business Media: Dordrecht, The Netherlands, 2007; Volume 92.

32. Marin, V.; Chelcea, L. The many (still) functional housing estates of Bucharest, Romania: A viable housing provider in Europe's densest capital city. In Housing Estates in Europe; Springer: Cham, Switzerland, 2018; pp. 167-190.

33. Mojović, Đ.; Stanković, Ž.; Čarnojević, V. Local Housing Policy; UDP: Belgrade, Serbia, 2009; Available online: http://www.pur.rs/en/publication/2/local-housing-policy (accessed on 6 September 2020).

34. Gruis, V.; Tsenkova, S.; Nieboer, N. Managing privatised housing: An international overview of developments and challenges. In Proceedings of the ENHR International Conference "Housing in an Expanding Europe: Theory, Policy, Participation and Implementation", Ljubljana, Slovenia, 2-5 July 2006.

35. Zakon o Nadziđivanju Zgrada i Pretvaranju Zajedničkih Prostorija u Stanove; "Sl. glasnik SRS", br. $24 / 88$ i "Sl. glasnik RS", br. 46/94.; Sluzbeni Glasnik: Belgrade, Serbia, 1994; Available online: http://www.podaci.net/ _zakon/propis/Zakon_o_nadzidjivanju/Z-nzpzps03v8824-9446.html (accessed on 5 June 2020).

36. Petovar, K.; Mojović, Đ. Condominium management and maintenance. Four strategic themes for the housing policy in Serbia. In Proceedings of the National Housing Conference Towards a New National Housing Policy for Serbia, UN-Habitat, SIRP Programme, Belgrade, Serbia, 6-7 July 2006.

37. Zakon o Planiranju i Izgradnji; (“Sl. Glasnik RS”, Br. 72/2009, 81/2009-Ispr., 64/2010—Odluka US, 24/2011, 121/2012, 42/2013_Odluka US, 50/2013_Odluka US, 98/2013-Odluka US, 132/2014, 145/2014, 83/2018, 31/2019, 37/2019_Dr. Zakon i 9/2020); Sluzbeni Glasnik: Belgrade, Serbia, 2020.

38. Murie, A.; Knorr-Siedow, T.; van Kempen, R. Large Housing Estates in Europe: General Developments and Theoretical Backgrounds (RESTATE Report 1); Faculty of Geosciences, Utrecht University: Utrecht, The Netherlands, 2003; Available online: http://restate.geo.uu.nl/results/Reports1,2/1ec.pdf (accessed on 12 July 2020).

39. Madanipour, A. Marginal public spaces in European cities. J. Urban Des. 2004, 9, 267-286. [CrossRef]

40. Woolley, H. Urban Open Spaces; Taylor \& Francis: London, UK, 2003.

41. Bogdanović Protić, I. Urbana Regeneracija Višespratnog Stanovanja; Zadužbina Andrejević: Belgrade, Serbia, 2009.

42. Protic, I.B.; Mitković, P.; Ljubenović, M. Criteria and aspects of quality of open spaces in high-rise housing neighbourhoods in the process of urban revitalization. Facta Univ. Ser. Archit. Civ. Eng. 2019, 17, 221-233. [CrossRef]

43. Dekker, K.; de Vos, S.; Musterd, S.; van Kempen, R. Residential satisfaction in housing estates in European cities: A multi-level research approach. Hous. Stud. 2011, 26, 479-499. [CrossRef]

44. Madanipour, A. Public and Private Spaces of the City; Routledge: London, UK, 2003.

45. Tibbalds, F. Making People-Friendly Towns: Improving the Public Environment in Towns and Cities; Taylor \& Francis: London, UK, 2012; Available online: https://doi.org/10.4324/9780203469521 (accessed on 25 July 2020).

46. Francis, M. Urban Open Space Designing for User Needs; Island Press: Washington, DC, USA, 2003. 
47. Lynch, K. Neighbourhood Parks in Saskatoon: Contributions to Perceptions of Quality of Life. Ph.D. Thesis, University of Saskatchewan, Saskatoon, SK, Canada, 2007.

48. Jacobs, A.; Appleyard, D. Toward an urban design manifesto. J. Am. Plann. Assoc. 1987, 53, 112-120. [CrossRef]

49. Bentley, L.; Alcock, A.; Murrain, P.; McGlynn, S.; Smith, G. Responsive Environments: A Manual for Designers; Architectural Press: London, UK, 1985.

50. Im, S.B. Visual preferences in enclosed urban spaces: An exploration of a scientific approach to environmental design. Environ. Behav. 1984, 16, 235-262. [CrossRef]

51. Gehl, J. Life between Buildings: Using Public Space; Island Press: Washington, DC, USA, 2011.

52. Bélanger, H. Public spaces in gentrifying neighbourhoods: Conflicting meanings. In Proceedings of the ENHR International Conference Sustainable Urban Areas, Rotterdam, The Netherlands, 25-27 June 2007; p. 13.

53. Dhar, T.K. Impact of Layout Design on Neighborly Interaction in Public Housing Estate. Ph.D. Thesis, University of Hong Kong, Hong Kong, China, 2007.

54. Hur, M.; Nasar, J.L.; Chun, B. Neighborhood satisfaction, physical and perceived naturalness and openness. J. Environ. Psychol. 2010, 30, 52-59. [CrossRef]

55. Curran, R.J. Architecture and the Urban Experience; Van Nostrand Reinhold: New York, NY, USA, 1983.

56. Ruland, G. Freiraumqualität im Geschosswohnungsbau: Diskussion über die Qualität der Freiraumplanung im mehrgeschossigen Wohnbau der 90er Jahre am Beispiel von Wien; Stadtentwicklung Wien, Magistratsabt. 18: Wien, Austria, 2002.

57. Bai, D.M. Residential Area Planning and Environment Design; China Building Industry Press: Beijing, China, 1993.

58. Li, Y. Space Between Buildings in Beijing's New Housing. Master's Thesis, McGill University, Montreal, QC,Canada, 1999. Available online: https://escholarship.mcgill.ca/concern/file_sets/9306t107m?locale=en (accessed on 3 June 2020).

59. Alexander, C. A Pattern Language: Towns, Buildings, Construction; Oxford University Press: Oxford, UK, 1977.

60. Kearns, A.; Parkinson, M. The significance of neighbourhood. Urban Stud. 2001, 38, 2103-2110. [CrossRef]

61. Coorey, S.B. Design of Open Spaces in High Density Zones: Case Study of Public Housing Estates in Hong Kong. Ph.D. Thesis, University of Hong Kong, Hong Kong, China, 2007.

62. Szafrańska, E. Transformations of large housing estates in post-socialist city: The case of Łódź, Poland. Geogr. Pol. 2014, 87, 77-93. [CrossRef]

63. Tanaka, Y. Continuity and transformation of open spaces in the large housing estate developed under socialism in Prague, Czech Republic. IOP Conf. Ser. Mater. Sci. Eng. 2019, 603, 042050. [CrossRef]

64. Kristiánová, K. Post-socialist transformations of green open spaces in large scale socialist housing estates in Slovakia. Proc. Eng. 2016, 161, 1863-1867. [CrossRef]

65. Can, I. In-Between Space and Social Interaction: A Case Study of Three Neighbourhoods in Izmir. Ph. D. Thesis, University of Nottingham, Nottingham, UK, 2012.

66. Castell, P. Dialogues and citizen initiatives in stigmatized urban areas: Reflections on the development of participatory planning principles in Gothenburg. In Proceedings of the IFHP 56th World Congress: Inclusive Cities in a Global World, The International Federation for Housing and Planning (IFHP), Gothenburg, Sweden, 16-19 September 2012; pp. 16-19.

67. Bogdanović-Protić, I.; Dinić-Branković, M.; Igić, M.; Ljubenović, M.; Mitković, M. Modalities of tenants participation in the revitalization of open spaces in complexes with high-rise housing. Facta Univ.-Ser. Archit. Civ. Eng. 2018, 16, 203-211. [CrossRef]

68. Gasperi, D.; Pennisi, G.; Rizzati, N.; Magrefi, F.; Bazzocchi, G.; Mezzacapo, U.; Stefani, M.C.; Sanyé-Mengual, E.; Orsini, F.; Gianquinto, G. Towards regenerated and productive vacant areas through urban horticulture: Lessons from Bologna, Italy. Sustain. Switz. 2016, 8, 1347. [CrossRef]

69. Statistical Office of the Republic of Serbia. Census of Population, Households and Dwellings in the Republic of Serbia; Statistical Office of the Republic of Serbia: Belgrade, Serbia, 2011.

70. Gradska Stambena Agencija Niš (HACN). Stambeni Profil Grada Nǐ̌a; Gradska Stambena Agencija Niš: Niš, Serbia, 2006; Available online: http://www.gu.ni.rs/wp-content/uploads/file/Stambena0609.pdf (accessed on 30 June 2020).

71. Muliuolytè, J. Rediscovering large scale housing estates in post socialist cities. J. Archit. Urban. 2013, 37, 51-58. [CrossRef] 
72. Clark, P.; Niemi, M.; Nolin, C. Green Landscapes in the European City, 1750-2010; Routledge: New York, NY, USA, 2016.

73. Grad Niš, Gradski savet za razvoj. Strategija Razvoja Grada Niša; Službeni List Grada Niša, br. 82/07; Grad Niš, Gradski savet za razvoj: Niš, Serbia, 2007; Available online: http://www.gu.ni.rs/wp-content/uploads/ file/071203strategija.pdf (accessed on 25 September 2020).

74. City Assembly \& City Housing Agency Nis. Housing Strategy of the City of Nis; UN-Habitat: Nis, Serbia, 2007.

Publisher's Note: MDPI stays neutral with regard to jurisdictional claims in published maps and institutional affiliations.

(C) 2020 by the authors. Licensee MDPI, Basel, Switzerland. This article is an open access article distributed under the terms and conditions of the Creative Commons Attribution (CC BY) license (http://creativecommons.org/licenses/by/4.0/). 